\title{
A PETRIFIED BASIDIOMYCETE FROM PATAGONIA
}

\author{
Rolf Singer and Sergio Archangelsky ${ }^{1}$
}

DURING THE first months of 1956, S. Archangelsky visited the southern part of the Province of Patagonia (formerly Gobernación of Santa Cruz), Argentina, in order to carry out a series of paleobotanical studies. At this opportunity, Dr. José M. de Giusto, geologist of the Y.P.F. (Yacimientos Petrolíferos Fiscales), was kind enough to give him a number of fossil cones of Araucaria belonging to the petrified forests of Santa Cruz. Together with this material, and originating from the same locality, went a fossil organism which was suspected to be a fungus growing on the wood of Araucaria, and, indeed, turned out to be a carpophore of an aphyllophoraceous basidiomycete belonging in the porebearing group usually referred to as polypores, and more specifically in the former form genus Fomes.

The location of the fossil forests is shown in the map, fig. 1. The fungus comes from the southern part of Estancia Bellavista, east of Cerro Tortuga. The stratigraphical position of the petrified forests of Santa Cruz has suffered some important modifications. It has been attributed to anything from the upper Triassic to the lower Cretaceous (and has even been included in the Eocene). They belong to the so-called Porphyritic Formation of the Jurassic of Santa Cruz which consists principally of porphyries and quartziferous porphyries, with the associated volcanic tuffs.

Only during the last few years has it become possible to define the age of the petrified forests of Santa Cruz as that of the Upper Mesojurassic. This was demonstrated by the discovery of certain fossils, especially of the anuran Notobatrachus degiustoi Reig, and the presence of Otozamites sanctae-crucis Fer., and the association of the fossil plants. To quote Stipanicic and Reig (1955), the zone of the petrified forests is now included in the Matilda Formation of the Upper Mesojurassic.

In the area of the petrified forests of Santa Cruz, the following three species have been recognized up to now:

Araucaria mirabilis (Speg.) Florin = Araucarites mirabilis Speg. = Proaraucaria mirabilis (Speg.) Wiel. (Brown, 1940) = Araucaria windhauseni Goth .

Pararaucaria patagonica Wieland (Wieland, 1935) Araucarites Sanctaecrucis Calder (Calder, 1953)

To these elements is now added the fungus in question. It may be assumed that the three species of conifers indicated above were the only trees in the association, and therefore the fungus was either a parasite or a saprophyte on the wood of one of them. Since the carpophore was found separated

\footnotetext{
1 Received for publication August 13, 1957.
}

from the larger trunks, it cannot be determined which species was the host of the fungus.

Fossil fungi have not previously been reported from Argentina with the exception of Geinitz's (1925) indication of a Hvlomites cf. zamitae Goepp. which was repeated in Kurtz's Atlas de las Plantas Fósiles de Argentina (p. 136). This specimen was found on a leaf frond of Taeniopteris in the Upper Triassic. The fungus we describe here is, however, the first in Patagonia and the first basidiomycete fossil found in Argentina, and, so far as we are aware, in South America.

The specimen on which we base our description, as well as all fossil specimens of higher plants originating from the petrified forests, is silicified, i.e. the organic tissues are replaced by silica.

The carpophore in question has the following characters (fig. 2) :

Carpophore hoof-shaped, $50 \mathrm{~mm}$. high, diameter near the lower surface (where it is broadest) $55 \times$ $40 \mathrm{~mm}$. (projecting $40 \mathrm{~mm}$.), rear portion directly and astipitatelv attached to remainders of the substratum (wood); pileous zonate, with convex concentric ridges and deeplv sulcate between the ridges; tubes irregularly, not distinctly, stratified althouoh the carpophore seems to be of the perennial tvpe ("Fomes" sensu lato), pores mostly round and 100 $250 \mu$ in diameter (small), with thick tramal walls (fig. 3).

Microscopic characteristics still partly visible; spores not seen, but it can be concluded from the size of the hymenial elements that the spores are not of the type of Fomes sensu str., i.e. they must be relatively small as in some Fomitopsis and all Phellinus species rec.; hymenium on the inner surface of some pores still visible, about 11-14 $\mu$ thick; individually (fig. 4) some cells, slightly protruding and septate at the base (11-13 $\times 3-5 \mu)$, subventricose with rounded apex, are either cystidioles or hyphal ends breaking through the hymenial layer; conspicuous cystidia and setae absent or not preserved; hyphae of the trama variable in size, mostly about $3.5 \mu$ in diameter, but some hyphal bodies reaching up to $28 \mu$ in diameter. (These data were obtained from a preparation polished and smoothed from a transverse section perpendicular to the tubes of the hymenophore near the lower surface of the carpophore. The preparation was about $350 \mu$ thick which was sufficient for transparence under oil immersion lens).

The carpophore representing the holotype was obviously a several years old specimen (i.e. rather old!) in which the tubes were either partly dislocated or lost. As in many overmature durable polypores, the best preserved elements of the hymenium are sterile cells, apparently cystidioles. 


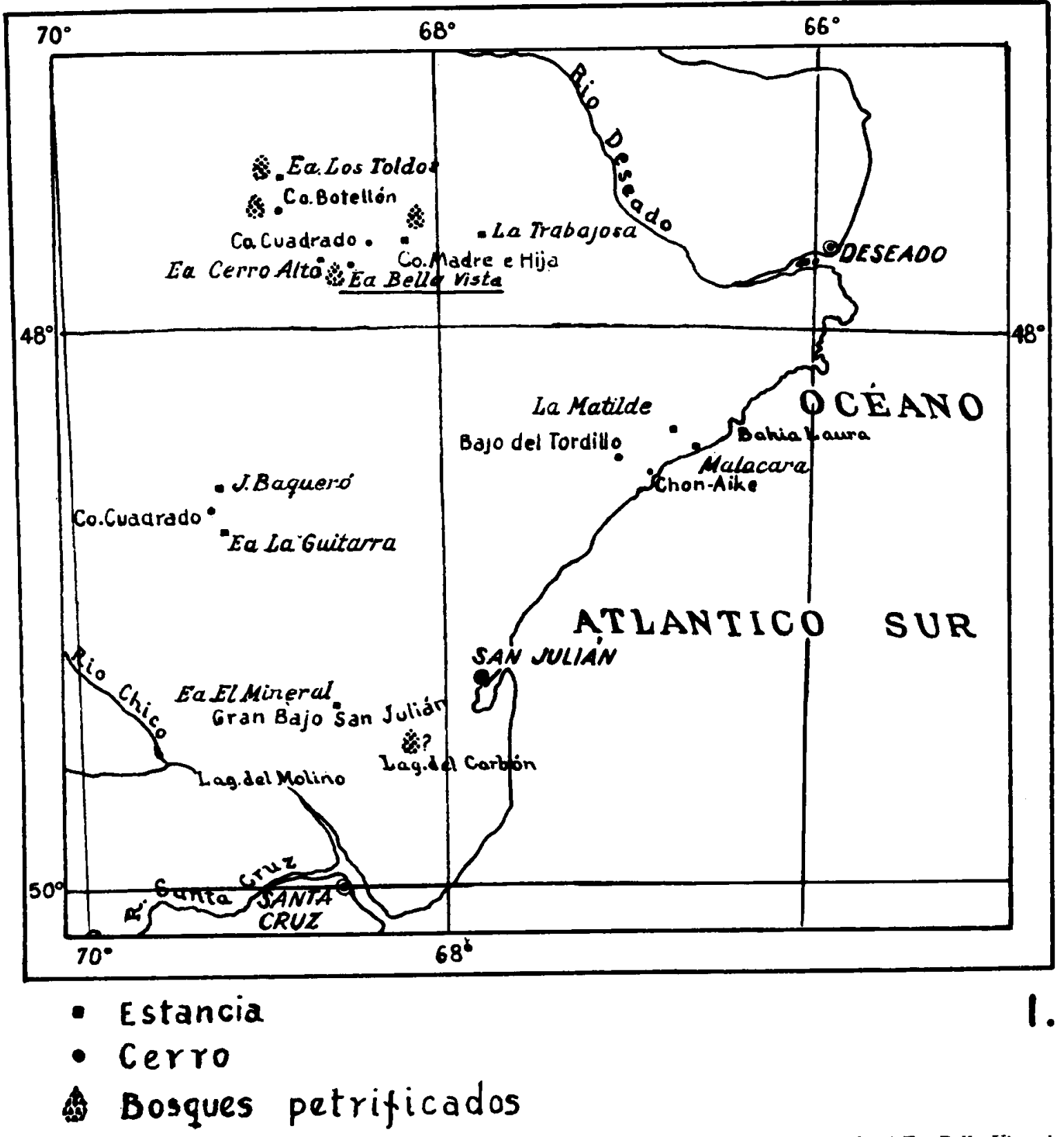

Fig. 1. Location of the petrified forests of Santa Cruz, Patagonia. The fungus was found south of Ea. Bella Vista just north of the $48 \mathrm{th}$ parallel and west of $68^{\circ}$ longitude. The dotted areas are the regions where petrified forests (Bosques petrificados) have been discovered. Cerro=mountain, estancia $=$ ranch.

The taxonomy of fossil polypores is at present rather confused. Three fossil genera of polyporaceous fungi have been described. One, Dactyloporus Herzer is based on a very characteristic form which, if really a polypore in the widest sense, is most certainly generically different from our specimen. Another, Polyporites Lindl. \& Hutt. is based on J. bowmanii Lindl. \& Hutt. which is probably a fish scale. Pseudopolyporus Hollick is the earliest generic name for any tube-bearing basidiomycete, but it might be a Polyporus (or related genus) in the narrower sense as well as any other (aphyllophoraceous) polypore, or even a bolete. It may be possible to obtain more descriptive data in order to decide in which family Pseudopolyporus really belongs, but it is quite certain from the description that it is generically different from the specimen discussed in the present paper. Meschinelli (1892) adds, furthermore, the following genera: Lenzitites, Daedaleites, and Trametites. None of the specimens 


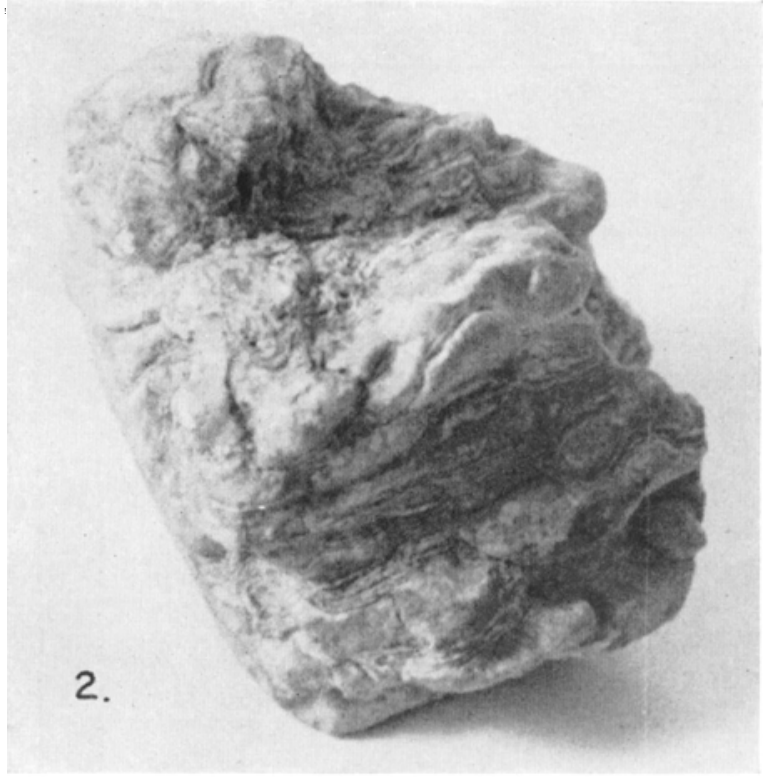

Fig. 2. Phellinites degiustoi Singer and Archangelsky. Entire carpophore in profile. Nat. Size. Phot. Sergio Archangelsky. described in these genera has the slightest similarity to our specimen, and only Trametites might possibly be related to it. However, since the type species is considered a form of Trametes pini, a recent species, Trametites might replace the genus Cryptoderma Imazeki (to which $T$. pini has now been transferred). Nevertheless, this presupposes the correctness of the original determination of the fossil, a presupposition which we cannot by any means admit. Thus, Trametites becomes a nomen dubium.

Consequently, the form genus Fomes as understood in the older and classical mycological literature is not represented by any fossil genus. The only fossil representatives of this form genus are Fomes idahoensis Brown, (1940) exclusively fossil, according to the author, and supposedly re-collected by Andrews and Lenz (1947), likewise in Idaho (U.S.A.) and Fomes applanatus (Pers. ex Fr.) Gill. (also a common living species). The fossil specimens of both are attributed to the Pliocene or Pleistocene.

The latter fossil Fomes, $F$. applanatus is, if correctly determined, a species of Ganoderma, and not conspecific or congeneric with our Patagonian species. The former, $F$. idahoensis, was compared

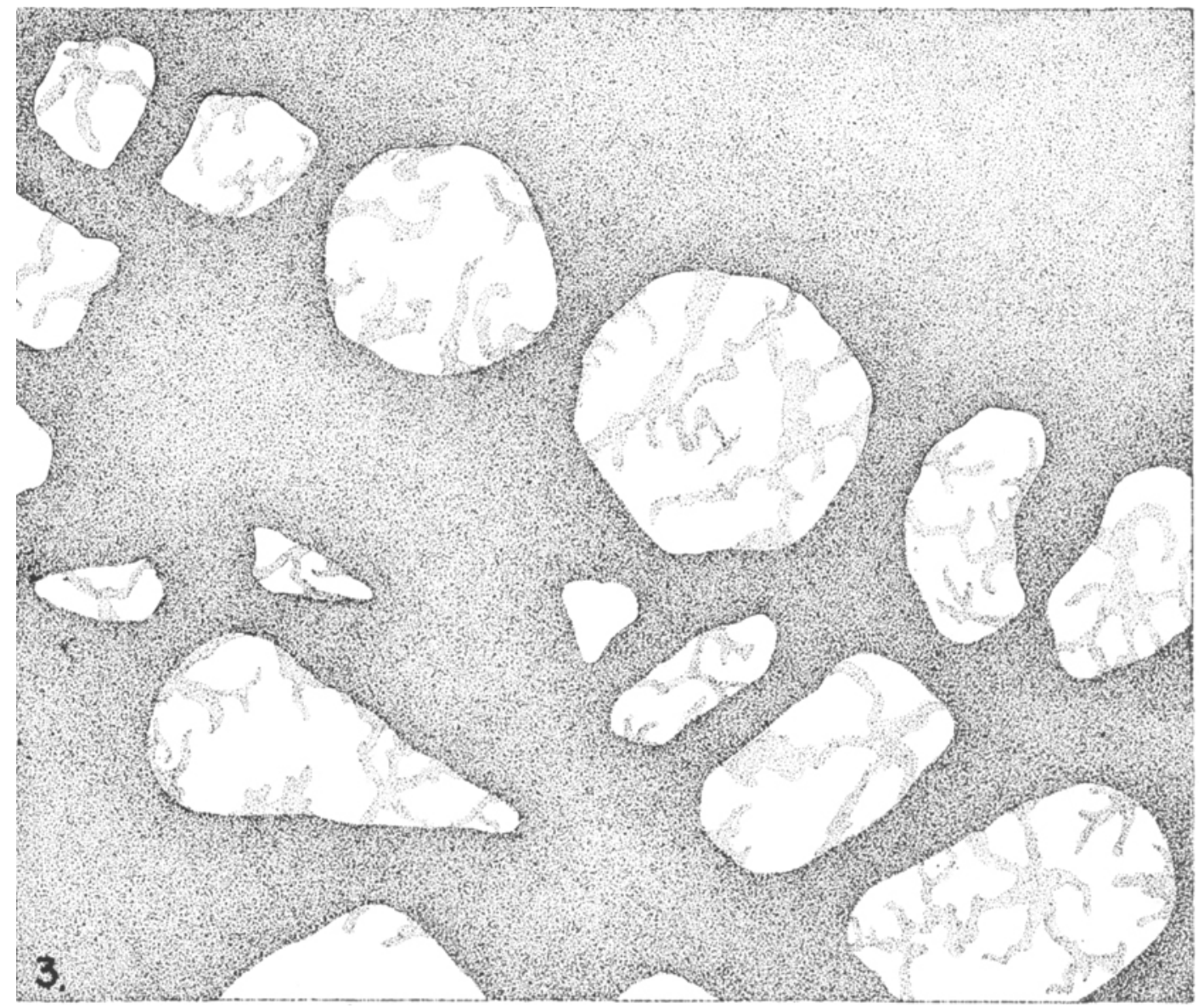

Fig. 3. Phellinites degiustoi Singer and Archangelsky. Section ground transversally to the tubes showing the pores. 


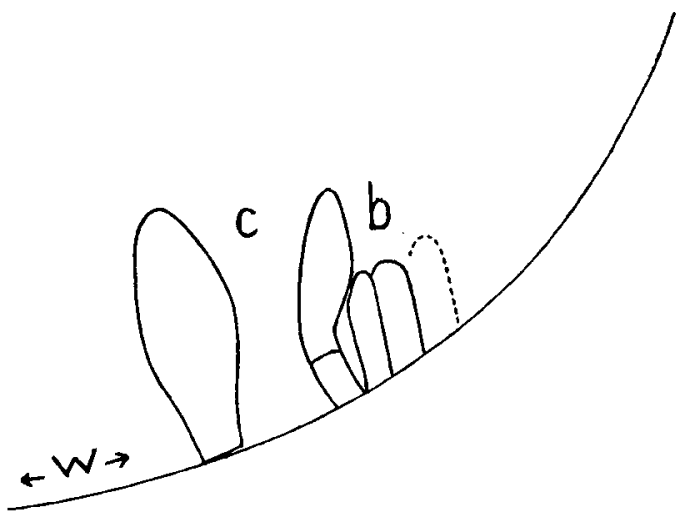

Fig. 4. Phellinites degiustoi Singer and Archangelsky. Elements of the hymenium as discernible in oil immersion; $w=$ surface of the tube wall (inner surface of tubes); $c=$ cystidioles; $b=$ basidia or basidioles; $\times 1000$.

by its author with the recent species Fomitopsis pinicola (Schwein.) Karst.

The characters by which the genera within the "Fomes" group (Fomitoideae) can be distinguished are mostly of a kind not evident in fossil material. The only genera of the subfamily which can be excluded with certainty are Cryptoporus, Piptoporus, Ischnoderma, Osmoporus, Phaeolus, Inonotus, Leucophellinus, Cyclomyces, Cycloporus, Coltricia, Fomes, Polystictus, and Ganoderma. In some cases, other than the one discussed in the present paper, it is conceivable that not even Fomes and Ganoderma could be identified with confidence in fossil material.

Under these circumstances, the fungus from Patagonia may be considered as certainly belonging to either one of the following genera: (1) Fomitopsis, (2) Phellinus, (3) a fossil genus of the Fomitoideae. until now unknown and not described. Although Brown (1940) has chosen the (then) easiest way of readapting the form-genus Fomes to paleobotany by merely using the genus Fomes in the widest sense for all the perennial genera of the Fomitoideae i.e., for the three possibilities enumerated above and likewise the genera Fomes sensu stricto and Ganoderma, we do not see fit to follow him in this taxonomic procedure. We believe that now, seventeen years after Brown's publication, his would still be a facile "solution" ad hoc but it would not take into consideration the modern concept of polypore taxonomy. For, the genus Fomes, being based on Fomes fomentarius as the nomenclatorial type, has now been restricted to this one species and its varieties (or "microspecies"). It is precisely this genus we are certain to be not congeneric with the Patagonian "Fomes." If Fomes were a generic name now abandoned for other reasons, it might still be permissible to use it as a form genus. But once restricted and redefined, this genus is not available for the Patagonian fungus.
It is therefore obvious that there is need for a fossil genus of fomitoid basidiomycetes which are not, or not necessarily, Fomes sensu stricto, i.e., congeneric with $F$. fomentarius, and which might belong to Fomitopsis, Phellinus, or a now extinct genus of similar habit and observable diagnostic characters.

We propose the new generic name Phellinites Sing. and Archangelsky for fomitoid species like the Patagonian one (and presumably also the Idaho "Fomes"), with the nomenclatorial type $\mathbf{P}$. digiustoi Sing. and Archangelsky.

Phellinites gen. nov., Aphyllophoralium porigerorum Fomitoidearum genus fossile; pileo forma magnitudineque speciebus pluristratosis generum recentium Fomitopsidis et $P$ hellini simillimo, zonatosulcato, tramate admodum crasso, poris minutis, stipite nullo; ad ligna nunc petrificata praecipue Coniferarum.

Phellinites digiustoi spec. nov. Carpophoro (basidiocarpo) ungulato $50 \mathrm{~mm}$. alto, ad basin $55 \times 40 \mathrm{~mm}$., zonis concentricis (cristis convexis sulcisque profundis alternantibus) praedito, porigero; poris $0.1-0.25 \mathrm{~mm}$. in diametro, irregulariter vel vix stratosis; elementis hymenii parvulis (diametro hymenii 11-14 $\mu$ ); setis haud visis. Ad ligna Araucariae fossilis aut Pararaucariae aut Araucaritis in "silva petrifacta" Mesojurassici Superioris in Santa Cruz, Prov. Patagonia, Argentina. Holo-typus in collectione palaeobotanica instituti "Miguel Lillo" conservatus est. No. 66.

Fomes idahoensis Brown probabiliter etiam hic spectat, ${ }^{2}$ at forma haud vel minus ungulata carpophori, superficie sterli minus fortiter zonata, aetate (aera) geologica multum recentiore a $P$. degiustoi manifeste differt.

\section{SUMMARY}

A fossil polypore described as Phellinites degiustoi Singer and Archangelsky genus nov., spec. nov. was found in Patagonia, in the area of a Jurassic petrified forest composed of Araucaria, Pararaucaria and Araucarites.

The Argentine specimen is the first fully determined fossil fungus of Argentina and, so far as the authors are aware, the the fossil basidiomycete from South America.

\section{Department of Botany \\ UNIVERSITY OF MiChIGAN \\ Ann Arbor, Michican AND \\ Departamento de Geologia \\ Instituto Miguel Lillo \\ Tucuman, Argentina}

2 We do not propose a transfer to Phellinites because it is quite possible that a revision of this obviously cenozoic fossil material would provide proof of its generic identity with Fomitopsis as hinted by Brown who stressed the similarity with $F$. pinicola. 


\section{LITERATURE CITED}

ANDrews, H. N. AND L. W. Lenz, 1947. Fossil polypores from Idaho. Ann. Missouri Bot. Gard. 34: 113-114.

Brown, R. W., 1940. A bracket fungus from the late Tertiary of southwestern Idaho. Jour. Wash. Acad. Science 30: 422-424.

Calder, M. G., 1953. A coniferous petrified forest in Patagonia. Bull. Brit. Mus. (Nat. Hist.) Geology 2 (2): 97-138.

Geinitz, H. B., 1925. Contribución a la paleontologia de la República Argentina. Sobre plantas y animales reticos de las provincias argentinas de La Rioja, San Juan y
Mendoza (traducido por G. Bodenbauer y N. de Anquin). Acta Acad. Nac. Cienc., Cordoba 8: 333-347. Meschineldi, A., 1892. Fungi fossiles in P. A. Saccardo, Sylloge fungorum omnium hucusque cognitorum 10: 741-808.

Stipanicic, P. N. and C. A. Reig, 1955. Breve noticia sobre el hallazgo de Anuros en el denominado "Complejo Porfirítico de la Patagonia Extraandina" con consideraciones acerca de la composición geológica del mismo. Rev. Asoc. Geol. Arg. 10: 215-233.

Wieland, G. R., 1935. The Cerro Cuadrado petrified forest. Carnegie Inst. Wash. Publ. 449.

\section{CYTOGENESIS AND ZONATION IN THE SHOO'T APEX OF CHRYSANTHEMUM MORIFOLIUM ${ }^{1}$}

\section{Richard A. Popham}

A RE-EXamination of the organization of both root and shoot promeristems of vascular plants has occurred within the past few years. Additional information has been sought in an attempt to ascertain the relationships existing between zonal organization of promeristems and growth at root and shoot apices. A brief resume of the trends of thought relating to the organization of root and shoot apices will be presented in order to enable the reader to more fully appreciate (1) the striking parallelism of the progression of concepts applied to the organization of root and shoot apices and (2) the present state of confusion existing in the literature relating to these areas of plant anatomy.

Insofar as root promeristems are concerned, three concepts have emerged. The oldest of these, the apical cell theory, was abandoned insofar as it applies to spermatophytes, by most anatomists shortly after the publication of Hanstein's (1868) classical paper in which the histogen theory was proposed. However, Nägeli's (1845) apical cell theory is now being proposed, in slightly modified form by Guttenberg (1947) and his associates as the basis for interpreting the growth of roots of gymnosperms and angiosperms. They cite evidence for the existence of a single apical cell from which tissues of the root are ultimately derived in much the same manner as in some pteridophytes.

It seems that proponents of the reformed apical cell theory of root histogenesis have had limited success in convincing root anatomists to abandon their established concepts of multicellular cytogenerative centers composed of histogens or zones of initials. It will be noted that these concepts of

1 Received for publication August 20, 1957.

Papers from the Department of Botany and Plant Pathology, The Ohio State University, No. 614.

Supported in part from funds granted to the Ohio State University by the Research Foundation for aid in funda. mental research. root histogenesis have one feature in common, i.e. whether it be one cell, a small group of cells, or a larger group of cells, which ultimately are responsible for root growth, they are thought to be located on or around the central longitudinal axis of the root a short distance back of the tip.

In direct opposition to the apical cell theory, the histogen theory, or modifications of them, stands a relatively recent proposal. By means of a $\mathrm{C}^{14}$ technique for the detection of DNA synthesis by cells of the root tip, root tip surgery, and other methods, Clowes $(1954,1956 \mathrm{a}, \mathrm{b})$ has presented evidence which casts considerable doubt on all previous explanations of root histogenesis. Clowes' evidence strongly suggests that the general region thought to be occupied by an apical cell, a group of initials, or one or more histogens is indeed a "quiescent centre" occupied by cells which "rarely or never divide and grow." If similar quiescent centres are eventually identified in the root apices of many plants, and the work of Clowes is verified, we will be forced to accept his inference that root tissue initials lie at the boundaries of a spheroidal group of quiescent cells.

Organizational patterns in shoot apices, and their relation to growth of shoots, have been quite thoroughly discussed by Popham (1951), Gifford (1954), and others. It will become obvious to the reader of these papers and to the reader of source material upon which they are based, that students of the shoot apex have interpreted the known facts so differently as to arrive at diametrically opposed concepts of how shoots grow. Furthermore, there is as yet no agreement upon a basic descriptive terminology.

It is doubtful that any anatomist seriously con. siders the probable existence of an apical cell of the pteridophyte type in shoot apices of spermatophytes or of histogens which invariably account for the perpetuation of specific tissues. These, however, 